\title{
Determination of Ursolic Acid and Ursolic Acid Lactone in the Leaves of Eucalyptus tereticornis by HPLC
}

\author{
Anupam Maurya and Santosh Kumar Srivastava* \\ Analytical Chemistry Division, Central Institute of Medicinal and Aromatic Plants, \\ 226015 Lucknow, India
}

\begin{abstract}
Um método simples, isocrático, de HPLC foi desenvolvido para quantificação simultânea de dois triterpenos bioativos, ácido ursólico e lactona do ácido ursólico em folhas de E. tereticornis. As amostras foram analisadas em coluna RP-18 $(4,6 \times 250 \mathrm{~mm}, 5 \mu \mathrm{m})$ com metanol e água acidificada a pH 3,5 com TFA (88:12) a $210 \mathrm{~nm}$. O método foi validado e aplicado para a quantificação simultânea dos triterpenos individuais em extrato de E. tereticornis. As curvas de calibração foram lineares no intervalo de concentração de 0,05 a $0,3 \mathrm{mg} \mathrm{mL}^{-1}(\mathrm{r}=0,999$ e 0,998 , respectivamente). Os limites de detecção e quantificação foram 0,190 e $0,644 \mu \mathrm{g}$ para ácido ursólico e 0,176 e 0,587 $\mu \mathrm{g}$ para lactona do ácido ursólico, enquanto as porcentagens de recuperação foram 97,32 e 96,23\% para ácido ursólico e lactona do ácido ursólico, respectivamente. Este é o primeiro relato sobre o método HPLC de lactona do ácido ursólico com alta precisão e exatidão.
\end{abstract}

A simple isocratic HPLC method has been developed for the simultaneous quantification of two bioactive triterpenes, ursolic acid and ursolic acid lactone in E. tereticornis leaves. Samples were analyzed on RP-18 $(4.6 \times 250 \mathrm{~mm}, 5 \mu \mathrm{m})$ column with methanol and water acidified to pH 3.5 with TFA (88:12) at $210 \mathrm{~nm}$. The method was validated and applied for the simultaneous quantification of the individual triterpenes in E. tereticornis extract. The calibration curves were linear over a concentration range of $0.05-0.3 \mathrm{mg} \mathrm{mL}^{-1}(\mathrm{r}=0.999$ and 0.998 , respectively). The limits of detection and quantification were 0.190 and $0.644 \mu \mathrm{g}$ for ursolic acid, and 0.176 and $0.587 \mu \mathrm{g}$ for ursolic acid lactone, while the percentage recoveries were 97.32 and $96.23 \%$ for ursolic acid and ursolic acid lactone, respectively. This is the first report on the HPLC method of ursolic acid lactone with high precision and accuracy.

Keywords: Eucalyptus tereticornis, HPLC, triterpenoids, ursolic acid, ursolic acid lactone

\section{Introduction}

Eucalyptus tereticornis Smith (Myrtaceae, Mysore Gum) extensively grown in various states of India. ${ }^{1}$ It is a valuable quick growing species grown on large scale for afforestation programmes throughout India for its use as a raw material for pulp wood industry. Eucalyptus is a popular medicine for abscess, arthritis, asthma, boils, bronchitis, burns, cancer, catarrh, cold, cough, croup, cystitia, diabetes, diptheria, dysentery, dyspepsia, fever, flu, grippe, inflammation, laryngitis, leprosy, malaria, miasma, phthisis, rhinitis, sores, sore throat, spasms, tuberculosis, tumors, vaginitis, wounds, and worms..$^{2-5}$

The leaves are a good source of essential oil, ${ }^{6}$ and in Ayurveda its oil is used as an antiseptic and for respiratory tract infections. Apart from the essential oil, a number of phytochemicals have been isolated from the various

*e-mail: santoshkumar_1955@yahoo.com parts of E. tereticornis such as, flavanoids, ${ }^{7}$ euglobal T1, ${ }^{8}$ triterpenoids as betulonic acid, tereticornate $\mathrm{A}$, tereticornate $\mathrm{B},{ }^{7}$ betulinic acid, ${ }^{9} 2 \alpha$-hydroxy ursolic acid, ursolic acid, ursolic acid lactone ${ }^{10}$ and $\beta$-sitosterol. ${ }^{9}$ After essential oil isolation, the leaves of E. tereticornis can be further utilized for large scale isolation of anticancer agent, ursolic acid (UA, 1) and ursolic acid lactone (UAL, 2) ${ }^{11}$ (Figure 1).

Ursolic acid has shown many important pharmacological activities, analgesic, anti-tumor, ${ }^{12}$ anti-bacterial,${ }^{13}$ diuretic, anti-diabetic, anti-oxidant, COX-2 inhibitor, antiinflammatory, ${ }^{14}$ hepatoprotective,,$^{15}$ anti-HIV ${ }^{16}$ and anti-cancer against various human cancer cell lines. ${ }^{17,18}$ Because of its anticancer activities, ursolic acid has been the subject of interest for preclinical anti-cancer research. On the other hand ursolic acid lactone has also shown antiproliferative activity against human gastric adenocarcinoma (MK1), uterine carcinoma (HeLa) and murine melanoma (B16F10) ${ }^{19}$ along with substantial antiinflammatory activity. ${ }^{20}$ 


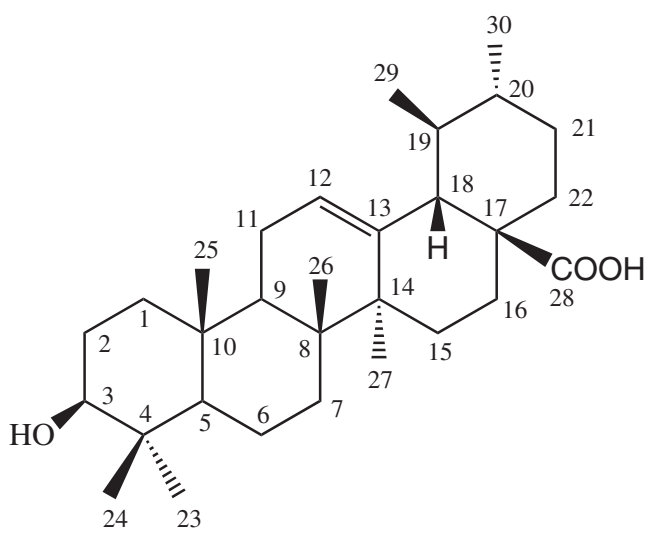

1

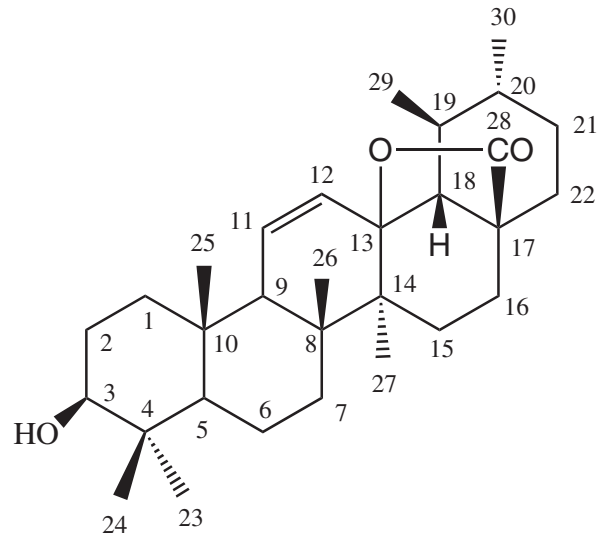

2

Figure 1. Chemical structures of ursolic acid (1) and ursolic acid lactone (2).

Although there are several HPLC analytical methods for ursolic acid from different plants, ${ }^{21-23}$ there is no HPLC method for the analysis of bioactive ursolic acid lactone as well as for UA (1) and UAL (2) in the leaves of E. tereticornis. Hence the objective of present work is to develop simple, rapid, precise and accurate method for determination of bioactive UA (1) and UAL (2) in the leaves of E. tereticornis for better evaluation and medicinal utilization of leaves in the future.

\section{Experimental}

Plant material

The leaves of E. tereticornis were collected from the medicinal farm of Central Institute of Medicinal and Aromatic Plants (CIMAP), Lucknow, Uttar Pradesh, India during the month of January, 2008. Voucher specimen (CIMAP N.12470) is deposited in the Botany and Pharmacognosy Department of the institute.

\section{Isolation and characterization of reference compounds}

The reference marker compounds, ursolic acid (1) and ursolic acid lactone (2) were isolated in $\geq 95 \%$ purity by fast centrifugal partition chromatography (FCPC) ${ }^{11}$ and characterized on the basis of their spectroscopic data (see Supplementary Information). ${ }^{7,24}$

\section{Sample preparation}

The dried leaves of E. tereticornis (100 mg) were extracted three times with ethyl acetate $(5 \mathrm{~mL})$ in an ultrasonic extractor (Micro clean -109 bath; Oscar India). All the extracts were combined and evaporated to dryness at $35^{\circ} \mathrm{C}$. The residue was dissolved in $1 \mathrm{~mL}$ methanol and filtered in $0.45 \mu \mathrm{m}$ membrane filtered through (Millipore).

\section{Chemicals and standards}

All the reagents and solvents used were of HPLC grade (E. Merck Ltd., Mumbai, India), while the reference marker compounds, ursolic acid (1) and ursolic acid lactone (2) were isolated in $\geq 95 \%$ purity as discussed above.

\section{Apparatus and chromatographic conditions}

A sonicator (Microclean 109, Oscar Ultrasonic, Mumbai, India) was used for sample preparation, The 300 MHz NMR (Avance, Bruker, Switzerland) was used to record ${ }^{1} \mathrm{H}$ and ${ }^{13} \mathrm{C}$ NMR.

A HPLC pump (Shimadzu, Tokyo, Japan), LC-10A equipped with Shimadzu SPD-M10 Avp (PDA set at $210 \mathrm{~nm}$ ) detector and Rheodyne injection valve with a $20 \mu \mathrm{L}$ loop was used. Ursolic acid (1) and ursolic acid lactone (2) were analyzed on a Water symmetry shield RP18 column $(4.6 \times 250 \mathrm{~mm}$ i.d., $5 \mu \mathrm{m}$, Waters $)$. The mobile phase used was a mixture of methanol-water acidified to pH-3.5 with TFA (88:12 v/v) with $1 \mathrm{~mL} \mathrm{~min}^{-1}$ flow rate. The HPLC system was operated at room temperature $25 \pm 1{ }^{\circ} \mathrm{C}$.

\section{Preparation of standard solution}

The stock solution of $1 \mathrm{mg} \mathrm{mL} \mathrm{m}^{-1}$ was prepared in methanol for standard markers UA (1) and UAL (2). A serial dilution was made for each stock solutions at concentrations of 50, 100, $200300 \mu \mathrm{g} \mathrm{mL}^{-1}$, by adding methanol and $20 \mu \mathrm{L}$ of each was used for plotting the standard curve for UA (1) and UAL (2), respectively. 


\section{Validation of HPLC method}

\section{Linearity (calibration curve)}

The linearity of the method for each standard was established by injection of $20 \mu \mathrm{L}$ of standard solution of different concentration. The linearity of UA (1) and UAL (2) were analyzed in triplicate. The calibration curves were constructed by plotting peak areas against analyte concentration. The linearity was assessed by calculating the slope, $y$-intercept and coefficient of determination $\left(r^{2}\right)$ using least squares regression equation.

\section{Limit of detection (LOD) and limit of quantification (LOQ)}

The linear regression equation of calibration curve was used to determine the LOD and LOQ. Under the chromatographic conditions employed in the current study, LOD $(\mathrm{S} / \mathrm{N}=3)$ and LOQ $(\mathrm{S} / \mathrm{N}=10)$ were determined for UA (1) and UAL (2).

\section{Precision and accuracy}

The repeatability (intra-day precision), the intermediate precision (inter-day precision) and the accuracy of the method were determined at three different concentrations. Samples were prepared by spiking stock standard solutions with ethyl acetate extract of E. tereticornis leaves. The intra-day and inter-day precision of the method for UA (1) and UAL (2) were measured by peak area determination of triterpenoids in triplicate.

The precision is expressed as \% RSD and the accuracy is expressed as the percentage recovery of the added triterpenoids.

\section{Recovery}

To determine the recovery percentage, a measured amount of $0.8 \mathrm{mg}$ each of UA (1) and UAL (2) were added to the ethyl acetate extract of E. tereticornis leaves and was analyzed according to the following formula,

Recovery $(\%)=(\mathrm{A}-\mathrm{B}) / \mathrm{C} \times 100 \%$

where $\mathrm{A}$ is the amount detected, B is the amount of sample without standards and $\mathrm{C}$ is the spiked amount of the standards.

All the statistical analysis was performed on the GraphPad Prism-5 (Graph Pad software, Inc., USA, 2008).

\section{Results and Discussion}

Triterpenoids show poor UV absorption due to lack of chromophore moieties in their chemical structures. This is the major limitation in the analysis of this class of compounds using UV detection. However, there are some reports on triterpenoids and saponins detection at low wavelength range ${ }^{25,26}$ in other plants. In some cases derivatization ${ }^{26}$ has also been used for the detection at higher wavelengths, but this additional step may results in significant error in the method. As discussed earlier, although there are several HPLC analytical methods for ursolic acid from different plants, ${ }^{21-23}$ there is no HPLC method for the analysis of bioactive ursolic acid lactone, hence this work was designed to develop a simple, rapid, precise and accurate method for UA (1) and UAL (2) determination in the leaves of E. tereticornis.

It was observed that the mobile phases used in earlier HPLC methods for ursolic and oleanolic acid determination were composed of three solvents, ${ }^{21}$ acetic acid, ${ }^{21} \mathrm{H}_{3} \mathrm{PO}_{4}$, and buffers. ${ }^{23}$ It has been common observation that frequent use of buffer in mobile phase reduces the life of column, HPLC pump, detector flow cell and creates high pressure. Therefore, use of TFA in HPLC methods to control $\mathrm{pH}$ and no ion pairing in acid is preferred in comparison to buffers. ${ }^{27}$

Different types of column and mobile phase compositions were carefully tested in order to determine the optimal chromatographic conditions. It was found that better separation and shapes peak were achieved with Waters Symmetry Shield RP-18 $(4.6 \times 250 \mathrm{~mm}, 5 \mu \mathrm{m})$ column at column temperature $25 \pm 1{ }^{\circ} \mathrm{C}$. For the mobile phase, separation using only methanol or water was unsatisfactory, but methanol as an organic modifier with an aqueous-TFA solution ( $\mathrm{pH}-3.5)$ performed well. In this case addition of TFA improved separation and peak shapes by controlling $\mathrm{pH}$ without any ion pairing for acidic analytes.

An isocratic system added simplicity, precision, accuracy, and minimized the variation at baseline. The above series of investigation led us to arrive at an optimal mobile phase for the simultaneous determination of UA (1) and UAL (2) in E. tereticornis leaf extract, namely methanol-water acidified to $\mathrm{pH}-3.5$ with TFA (88:12 v/v)

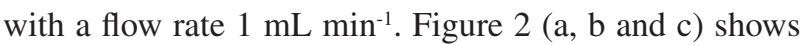
the HPLC chromatogram detected at $210 \mathrm{~nm}$.

For validation of analytical methods, the guidelines of International Conference on the Harmonization $\left[\mathrm{ICH}-\mathrm{Q} 2(\mathrm{R} 1)^{28}\right]$ recommend accomplishment of accuracy tests, precision and linearity of the method. The type of method and its respective use determine the parameter to be evaluated, especially, when the samples are complex biological matrices, as the case of herbal extracts UA (1) and UAL (2) presented retention time of 9.7 and $16.4 \mathrm{~min}$. The calibration curves for UA and UAL were linear in the range of $0.05-0.3 \mathrm{mg} \mathrm{mL}^{-1}$. The representative linear equations between peak area $(\mathrm{y})$ against concentration $(\mathrm{x})$ 

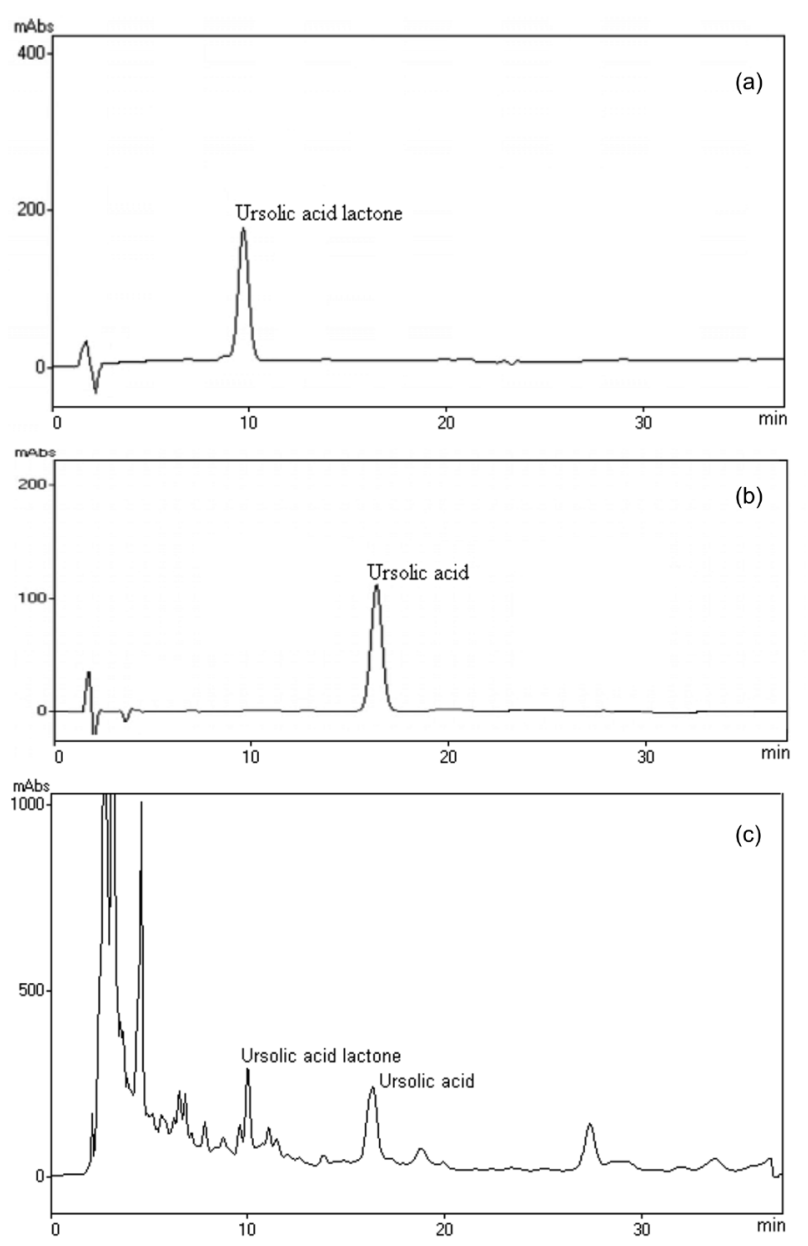

Figure 2. HPLC chromatograms of standards (a) UAL (r.t. $=9.8 \mathrm{~min}$ ), (b) UA (r.t. $=16.3 \mathrm{~min}$ ), and (c) ethyl acetate extract of E. tereticornis leaf (UAL: r.t. $=9.7 \mathrm{~min}, \mathrm{UA}:$ r.t. $=16.4 \mathrm{~min}$ ) detection at $210 \mathrm{~nm}$.

were $\mathrm{Y}=394113 \mathrm{x}+513665\left(\mathrm{r}^{2}=0.999\right)$ and $\mathrm{Y}=353923 \mathrm{x}+$ $450929\left(r^{2}=0.998\right)$. The correlation coefficients were greater than $0.99\left(r^{2}>0.998\right)$ indicating high degree of correlation and good linearity of the method.

The limit of detection (LOD), which can be detected but not necessary quantified under the stated experimental condition, were 0.190 and $0.176 \mu \mathrm{g}$ for UA (1) and UAL (2) respectively. The limit of quantification, which can be determined with acceptable precision and accuracy, were 0.644 and $0.587 \mu$ g for UA (1) and UAL (2), respectively. These results indicate that the method provided adequate sensitivity. The intra-day and inter-day precision of the method for UA (1) and UAL (2) were measured by peak area determination of triterpenoids in triplicate. The low value of $\% \operatorname{RSD}(<2 \%)$ reflect the high precision of the method. The percentage recoveries for the intra-day accuracy were 97.32-98.45 and 96.25-97.51 and those for inter-day accuracy were 97.51-98.27 and 96.31-97.15 for UA (1) and UAL (2) respectively. Both percentage recoveries were within 96.3-98.5 indicating good accuracy of the method. The method was used to quantify the amount of UA (1) and UAL (2) in 5 samples of ethyl acetate extract of E. tereticornis leaves. The percentages of UA (1) and UAL (2) in the E. tereticornis ethyl acetate extract were $1.7 \pm 0.15 \%$ and $0.8 \pm 0.04 \%(\mathrm{~m} / \mathrm{m})$, respectively. In our method UA has been detected at $16.3 \mathrm{~min}$, while in a previous method it was detected at $19.5 \mathrm{~min}$. In this way our method has a time advantage of $16.4 \%$ over the previous method. Another advantage of our method is the low acidic $\mathrm{pH}$ (3.5) of mobile phase in comparison to the high acidic $\mathrm{pH}(2.8)$ in the previous method. ${ }^{23}$

\section{Conclusions}

In this study, we developed a simple, precise, and accurate HPLC method for the simultaneous quantification of ursolic acid (1) and ursolic acid lactone (2) in leafs of E. tereticornis. The experimental conditions, including the mobile phase composition, column temperature and flow rate were optimized to provide high resolution and reproducible peaks. From preliminary experiments, the best results were obtained using a mobile phase of methanol: water acidified to $\mathrm{pH} 3.5$ with TFA $(88: 12, \mathrm{v} / \mathrm{v})$. A flow rate of $1 \mathrm{~mL} \mathrm{~min}{ }^{-1}$ was found to be appropriate for shortening the run time without compromising the peak resolution. A controlled column temperature of $25 \pm 1{ }^{\circ} \mathrm{C}$ was required to obtain reproducible results. The method was validated in compliance with the International Conference on Harmonization (ICH) guideline [ICH-Q2 (R1) ${ }^{28}$ and is suitable for the simultaneous determination of individual triterpenoids in the leaf extract of E. tereticornis with excellent precision, accuracy, and linearity. The method is isocratic with an uncomplicated mobile phase, and the sample preparation and assay procedures are simple and rapid. This is for the first time, a HPLC method for the quantitative determination of ursolic acid lactone (UAL, 2) has been developed with high precision and accuracy. Therefore we suggest that this method can be routinely used for the analysis of UA (1) and UAL (2) in the extracts and formulations containing E. tereticornis leaves.

\section{Supplementary Information}

Supplementary data are available free of charge at http://jbcs.sbq.org.br as PDF file.

\section{Acknowledgments}

Financial support for this research by CSIR Network project NWP 09 is gratefully acknowledged. We also thank all of our colleagues for their excellent assistance. 


\section{References}

1. Qureshi, M.; Indian Forester 1966, 92, 213.

2. Watt, J. M.; Breyer-Brandwijk, M. G.; The Medicinal and Poisonous Plants of Southern and Eastern Africa, $2^{\text {nd }}$ ed., E\&S Livingstone, Ltd.: Edinburgh, London, 1962.

3. Duke, J. A.; Wain, K. K.; Medicinal Plants of the World (computer index with more than 85,000 entries), 1981, vol. 3.

4. List, P. H.; Horhammer, L.; Hager's Handbuch der Pharmazeutischen Praxis, Springer-Verlag: Berlin, 1969-1979, vol. 2-6.

5. Morton, J. F.; Atlas of Medicinal Plants of Middle America: Bahamas to Yucatan, Thomas, C. C., ed.: Springfield, IL, 1981.

6. Rao, H. S.; Shiva, M. P.; Jain, P. P.; Indian Forester 1970, 96, 135 .

7. Hongcheng, W.; Fujimotot, Y.; Phytochemistry 1993, 33, 151.

8. Kokumai, M.; Konoshima, T.; Kazuka, M.; Haruna, M.; Ito, K.; J. Nat. Prod. 1991, 54, 1082.

9. Theagarajan, K. S.; Prabhu, V.V.; Indian Journal of Forestry 1983, 6, 238.

10. Dayal, R.; Current Science 1987, 56, 670.

11. Maurya, A.; Srivastava, S. K.; Sep. Sci. Technol. 2011, 46, 1189.

12. Young, H. S.; Chung, H. Y.; Lee, C. K.; Park, K. Y.; Yokosawa, T.; Qura, H.; Biol. Pharm. Bull. 1994, 17, 990.

13. Kowalewski, Z.; Kortus, M.; Edzia, W.; Koniar, H.; Arch. Immunol. Ther. Exp. (Warsz) 1976, 24, 115.

14. Vasconcelos, M. A.; Royo, V. A.; Ferreira, D. S.; Crotti, A. E.; Andrade e Silva, M. L.; Z. Naturforsch. C 2006, 61, 477.

15. Saraswat, B.; Visen, P. K.; Agarwal, D. P.; Phytother. Res. 2000, 14, 163.
16. Kasiwada, Y.; Nagao, T.; Hashimoto, A.; Ikeshiro, Y.; Okabe, H.; Cosentino, L. M.; Lee, K. H.; J. Nat. Prod. 2006, 63, 1619.

17. Novotny, L.; Vachalkaova, A.; Biggs, D.; Neoplasma 2001, 48, 241.

18. Lee, K.; Lin. Y.; Wu, T.; Zhang, D.; Yamagishi, T.; Planta Med. 1988, 54, 308.

19. Yoshida, M.; Fuchigami, M.; Nagao, T.; Okabe,H.; Matsunaga, K.; Biol. Pharm. Bull. 2005, 28, 173.

20. Banno. N.; Akihisa, T.; Tokuda, H.; Yasukawa, K.; Taguchi, Y.; Biol. Pharm. Bull. 2005, 28, 1995.

21. Zacchigna, M.; Cateni, F.; Faudale, M.; Sosa, S.; Loggia, R. D.; Sci. Pharm. 2009, 77, 79.

22. Chen, J. H. Z.; Xia, H.; Tan, R. X.; J. Pharm. Biomed. Anal. 2003, 32, 1175.

23. Zhou, C.; Chen, K.; Sun, C.; Chen, Q.; Zhang. W.; Li, X.; Biomed. Chromatogr. 2007, 21: 755.

24. Seebacher, W.; Simic, N.; Weis, R.; Saf, R.; Kunert, O.; Magn. Reson. Chem. 2003, 41, 636 .

25. de Oliveira, B. H.; Santos, C. A. M.; Espindola, A. P. D. M.; Phytochem. Anal. 2002, 13, 95.

26. Vidal-Oliver, E.; Babadjamian, A.; Maillard, C.; Elias, R.; Balansard, G.; Pharm. Acta Helv. 1989, 64, 156.

27. Bielejewska, A.; Glód, B. K.; Chem. Anal. 2005, 50, 387.

28. International Conference on Harmonization; Validation of Analytical Procedures: Text Methodology ICH-Q2 (R1), Genava, 2005.

Submitted: May 13, 2011

Published online: January 24, 2012 